Western North American Naturalist 68(2), (C) 2008, pp. 153-160

\title{
DIET OF THE MOGOLLON VOLE AS INDICATED BY STABLE-ISOTOPE ANALYSIS $\left(\delta^{13} \mathrm{C}\right.$ AND $\left.\delta^{15} \mathrm{~N}\right)$
}

\author{
Carol L. Chambers ${ }^{1}$ and Richard R. Doucett ${ }^{2}$
}

\begin{abstract}
There are no published studies on the diet of Mogollon voles (Microtus mogollonensis) although this species occurs throughout the Southwest in montane forestlands. Mogollon voles are believed to be herbivorous, selecting the vegetative portion of grass as their dominant food source. Herbivores frequently select more easily digested $\mathrm{C}_{3}$ plants over $\mathrm{C}_{4}$ plants; we thus expected Mogollon voles would feed primarily on $\mathrm{C}_{3}$ plants. We collected hair samples from Mogollon voles captured in northern Arizona between 1967 and 2003 and plant samples from some capture sites. Then we compared stable carbon $\left(\delta^{13} \mathrm{C}\right)$ and nitrogen $\left(\delta^{15} \mathrm{~N}\right)$ isotope ratios to investigate dietary preferences for $\mathrm{C}_{3}$ or $\mathrm{C}_{4}$ plants. Mean isotope ratios for $\mathrm{C}_{3}$ plants we sampled were $-26.84 \% o(s=0.17)$ for $\delta^{13} \mathrm{C}$ and $-0.02 \%$ ( $\left.s=0.32\right)$ for $\delta^{15} \mathrm{~N}$. For $\mathrm{C}_{4}$ plants, mean isotope ratios for $\delta^{13} \mathrm{C}$ and $\delta^{15} \mathrm{~N}$ were $-15.04 \% o(s=0.38)$ and $-0.74 \%$ o $(s=0.55)$, respectively. Mogollon voles were largely herbivorous based on $\delta^{15} \mathrm{~N}$ (mean and standard error: $3.77 \pm 0.17 \%$ ) and used $\mathrm{C}_{3}$ plants more than $\mathrm{C}_{4}$ based on $\delta^{13} \mathrm{C}(-24.21 \pm 0.14 \%$ ). Activities that lead to changes in plant species composition or reduction in $\mathrm{C}_{3}$ plants in montane grasslands and forests (e.g., excessive ungulate grazing) may reduce habitat quality for Mogollon voles.
\end{abstract}

Key words: Mogollon vole, Microtus mogollonensis, carbon stable isotope, nitrogen stable isotope, diet, livestock grazing, Arizona.

The Mogollon vole, Microtus mogollonensis, distinct from the Mexican vole, M. mexicanus (Frey and LaRue 1993, Frey and Yates 1995), is found in mountainous areas of Arizona, New Mexico, Utah, Colorado, and Texas. Mogollon voles typically are associated with ponderosa pine, Pinus ponderosa, and mixed-conifer forests, where they inhabit dry grassy areas and riparian areas (Armstrong 1972, Kime et al. 1995, Winstead et al. 1999).

There are no published studies on the diet of Mogollon voles (Frey 1995), and available information is limited to analysis of stomach or fecal pellet contents. In general, Microtus species are more abundant in areas with higher amounts of graminoid vegetation, because voles use this for both food and cover (Tamarin 1985). The Mogollon vole is believed to be primarily herbivorous. Conley (1976) stated that the vegetative portion of grass is the dominant food source, and a preferred food is Kentucky bluegrass (Poa pratensis). Hilton (1976) found grasses and forbs as primary stomach contents from animals captured throughout the year in dry high-elevation meadows in northern Arizona. The Hualapai vole (formerly M. mexicanus hualpaiensis) feeds on green plant mate- rial as evidenced from bright green fecal pellets on runways (Spicer et al. 1985).

Stable-isotope analysis can be a useful technique for determining diet, because stable-isotope signatures from assimilated foods are directly incorporated into tissues of the consumer. Carbon and nitrogen stable-isotope ratios $\left(\delta^{13} \mathrm{C}\right.$ and $\delta^{15} \mathrm{~N}$, respectively) are useful in determining source and flow of energy (Kelly 2000). In general, $\delta^{15} \mathrm{~N}$ is enriched $3-5$ per mil (\%o) from producer to consumer and thus can indicate an organism's trophic level (DeNiro and Epstein 1981, Gannes et al. 1998, Kelly 2000). Diet can also be documented based on the carbon-isotopic distinction between $\mathrm{C}_{3}$ or $\mathrm{C}_{4}$ photosynthesis, because the carbon-isotopic composition of the consumer directly reflects its diet (DeNiro and Epstein 1978). The $\mathrm{C}_{3}$ pathway is common in dicots (e.g., yarrow, Achillea millefolium) and cool-season grasses (those that flower in late spring and early summer such as Arizona fescue, Festuca arizonica). The $\mathrm{C}_{4}$ photosynthetic pathway is common in warm-season grasses (those that flower during summer, e.g., blue grama, Bouteloua gracilis). Because the difference in $\delta^{13} \mathrm{C}$ values of $\mathrm{C}_{3}$ (range -35 to $-21 \%$ ) versus $\mathrm{C}_{4}$ (range -14 to

${ }^{1}$ School of Forestry, Box 15018, Northern Arizona University, Flagstaff, AZ 86011. E-mail: carol.chambers@nau.edu

${ }^{2}$ Colorado Plateau Stable Isotope Laboratory, Box 5640, Northern Arizona University, Flagstaff, AZ 86011. 
$-10 \%$ ) plants is large, classifying diet can add information on use of foods (Boutton 1991, Ehleringer 1991, Kelly 2000).

Hair is a biological archive of carbon- and nitrogen-stable-isotope ratios because it is composed of keratin derived in part from exogenous sources such as food and water. Because hair is relatively inert and resistant to degradation, the isotope composition reflects diet at the time hair growth occurred (Macko et al. 1999, West et al. 2004).

We investigated diet of Mogollon voles using stable-isotope analysis of hair. Because many herbivores select $\mathrm{C}_{3}$ over $\mathrm{C}_{4}$ plants for grazing (e.g., Gannes et al. 1998), we hypothesized that the diet of voles would reflect the $\mathrm{C}_{3}$ photosynthetic pathway. We hypothesized that the $\delta^{15} \mathrm{~N}$ would indicate that voles are herbivorous, with a $3-5 \%$ increase in their nitrogen stable isotope ratios over plant (producer) stable-isotope ratios in areas where Mogollon voles were captured. We also suspected that hair might serve as a sensitive indicator of climatic conditions (amount of precipitation) as reflected by carbon-stable-isotope enrichment in plants (e.g., enrichment during drier years because during dry conditions plants open stomata less during photosynthetic uptake of carbon dioxide $\left[\mathrm{CO}_{2}\right]$ to avoid desiccation. Plants take in less external $\mathrm{CO}_{2}$, the internal $\mathrm{CO}_{2}$ concentration inside the plant cell decreases, and the plant must use relatively more ${ }^{13} \mathrm{CO}_{2}$ than under moister conditions; Elheringer et al. 1993, Adams and Kolb 2004). We captured Mogollon voles or sampled them from the Northern Arizona University museum collection and collected representative plants at some capture sites to test our hypotheses.

\section{Study Sites}

We captured Mogollon voles by live-trapping in 3 riparian and 4 dry meadows from 2001 to 2003. Meadows were located within 100 $\mathrm{km}$ of Flagstaff on the Coconino and Kaibab National Forests. Riparian meadows were dominated by grasses and sedges including Kentucky bluegrass, clustered field sedge (Carex praegracilis), western wheatgrass (Pascopyrum smithii), deer muhly (Muhlenbergia rigens), and spike muhly (M. wrightii; C. Chambers unpublished data, Steed 2001); dry meadows were dominated by Arizona fescue and blue grama (Yarborough 2006). Ponderosa pine forest surrounded meadows. In northern Arizona, annual precipitation averages $55 \mathrm{~cm}$. The average high and low temperatures are $17.3^{\circ} \mathrm{C}$ and $-0.9^{\circ} \mathrm{C}$, respectively. During our trapping years, the study sites received 45,33 , and $45 \mathrm{~cm}$ of precipitation for 2001, 2002, and 2003, respectively (Western Regional Climate Center 2006).

\section{METHODS}

Vole Hair Samples

We placed 60-180 traps in each meadow for 2-5 days. We checked traps daily and identified captured animals to species, gender, and reproductive status. Using Winstead et al. (1999), we weighed and categorized Mogollon voles as juveniles, subadults, or adults with weight categories of $<17 \mathrm{~g}, 17.1-25 \mathrm{~g}$, or $>25$ g, respectively. We removed approximately 1 $\mathrm{mg}$ of hair from the dorsal surface of 68 voles captured in riparian meadows in June $2001(n$ $=8)$, October $2001(n=6)$, June $2002(n=$ 23), June $2003(n=6)$, and in dry meadows in July-August $2002(n=18)$ and $2003(n=7)$. Hair was stored frozen in individual vials prior to analysis. Animals were captured and handled under guidelines of the American Society of Mammalogists and with approval of the Northern Arizona University (NAU) Institutional Animal Care and Use Committee (Protocols 00-011 and 02-072).

Voles typically undergo synchronous molting (al-Khateeb and Johnson 1971, Lidicker 1973, Kuhlmann et al. 2003), and adults generally molt twice a year (late spring-early summer and fall; Lidicker 1973, Cherry and Verner 1975). We assumed that isotope signatures of adult Mogollon voles captured during summer and early fall indicated summer diet and that signatures of those captured during winter and spring indicated winter diet. Subadult-to-adult molt can occur within 2-3 months of age (Martin 1956). Subadult and juvenile voles that we captured were dispersing individuals, and we assumed they had lost any weaning signature after 3 weeks of age (M.D. Dearing, University of Utah, personal communication).

We obtained hair from 23 Mogollon voles in the NAU mammals collection to increase our sample size and scope of inference temporally and spatially (Appendix). These animals, collected between 1967 and 1979, represented captures from spring (Mar-May, $n$ $=4$ ), summer (Jun-Aug, $n=11$ ), fall (Sep-Nov, $n=6$ ), and winter (Dec, Feb, $n=2$ ) at 12 
TABLE 1. Precipitation measurements $(\mathrm{cm})$ and mean and standard error for $\delta^{13} \mathrm{C}$ and $\delta^{15} \mathrm{~N}$ from hair samples from Mogollon voles (Microtus mogollonensis) that were captured in riparian and dry meadows in northern Arizona, 2001-2003, and from Mogollon voles that were collected in northern Arizona between 1967 and 1979 and curated in the Northern Arizona University Mammals Collection. Means for $\delta^{13} \mathrm{C}$ with the same letter and means for $\delta^{15} \mathrm{~N}$ with the same letter were not significantly different $(P>0.05)$.

\begin{tabular}{|c|c|c|c|c|c|c|c|c|c|}
\hline \multirow[b]{2}{*}{ Locationa $^{a}$} & \multirow[b]{2}{*}{ Year } & \multirow[b]{2}{*}{$n$} & \multicolumn{3}{|c|}{$\delta^{13} \mathrm{C}$} & \multicolumn{3}{|c|}{$\delta^{15} \mathrm{~N}$} & \multirow{2}{*}{$\begin{array}{c}\text { Precipitation }^{\mathrm{b}} \\
(\mathrm{cm})\end{array}$} \\
\hline & & & $\bar{x}$ & $s_{\bar{x}}$ & & $\bar{x}$ & $s_{\bar{x}}$ & & \\
\hline Collection & $1967-1979^{c}$ & 23 & -23.2 & 0.3 & $\mathrm{c}$ & 3.9 & 0.6 & $\mathrm{c}$ & - \\
\hline Riparian & Oct 2001 & 6 & -25.7 & 0.1 & $\mathrm{a}$ & 3.2 & 0.2 & abc & 43.8 \\
\hline Riparian & Jun 2001 & 8 & -25.6 & 0.1 & a & 3.8 & 0.2 & $\mathrm{ac}$ & 41.7 \\
\hline Riparian & Jun 2003 & 6 & -25.3 & 0.2 & $\mathrm{a}$ & 3.6 & 0.4 & $\mathrm{ac}$ & 42.9 \\
\hline Dry & Jun 2003 & 7 & -24.9 & 0.4 & $a b$ & 5.4 & 0.7 & bc & 42.9 \\
\hline Riparian & Jun 2002 & 23 & -24.4 & 0.1 & $\mathrm{~b}$ & 3.6 & 0.1 & $\mathrm{ac}$ & 27.8 \\
\hline Dry & Jul 2002 & 18 & -23.4 & 0.2 & c & 3.4 & 0.1 & $\mathrm{a}$ & 27.3 \\
\hline
\end{tabular}

a Locations of 3 riparian $\left(35^{\circ} 2^{\prime} 27^{\prime \prime} \mathrm{N}, 111^{\circ} 34^{\prime} 28^{\prime \prime} \mathrm{W}, 2140 \mathrm{~m}\right.$ elevation; $35^{\circ} 3^{\prime} 56^{\prime \prime} \mathrm{N}, 111^{\circ} 34^{\prime} 58^{\prime \prime} \mathrm{W}, 2100 \mathrm{~m}$ elevation; $34^{\circ} 32^{\prime} 19^{\prime \prime} \mathrm{N}, 111^{\circ} 10^{\prime} 53^{\prime \prime} \mathrm{W}, 2125 \mathrm{~m}$ elevation) and 4 dry meadows $\left(35^{\circ} 3^{\prime} 57^{\prime \prime} \mathrm{N}, 111^{\circ} 38^{\prime} 36^{\prime \prime} \mathrm{W}, 2104 \mathrm{~m}\right.$ elevation; $35^{\circ} 8^{\prime} 50^{\prime \prime} \mathrm{N}, 112^{\circ} 8^{\prime} 17^{\prime \prime} \mathrm{W}, 2173 \mathrm{~m}$ elevation; $35^{\circ} 9^{\prime} 41^{\prime \prime} \mathrm{N}, 112^{\circ} 10^{\prime} 19^{\prime \prime} \mathrm{W}, 2187 \mathrm{~m}$ elevation; $35^{\circ} 27^{\prime} 1^{\prime \prime} \mathrm{N}, 111^{\circ} 53^{\prime} 10^{\prime \prime} \mathrm{W}, 2439$ m elevation).

${ }^{\mathrm{b}}$ Total precipitation from previous year to capture month (e.g., if capture month was October, precipitation was from November previous year to October capture month); not calculated for specimens from the Northern Arizona University Mammals Collection.

$\mathrm{c}_{n}=22$ for $\delta^{15} \mathrm{~N}$

sites. Because we did not have weights for these individuals, we could not categorize them as adults, subadults, or juveniles; they were excluded from analyses testing for age class differences.

\section{Vegetation Samples}

We collected representative samples from understory plants in areas we trapped, categorizing the species as high (dominant), moderate, or low density, and noted plants that covered Mogollon vole runways or showed signs of herbivory by voles.

\section{Stable-Isotope Analysis}

Prior to analysis, all hair samples were cleaned using a mild liquid detergent to remove dirt and then washed in a solvent mixture (chloroform:methanol, 2:1, v/v) to remove oils. Hair samples were then rinsed thoroughly with DI water and dried for $24-48$ hours at $60^{\circ} \mathrm{C}$. Plant samples were dried at $60^{\circ} \mathrm{C}$ for 48 hours and then ground to a fine powder using a ballmill grinder. Samples were weighed (about 1 $\mathrm{mg}$ for hair and $4 \mathrm{mg}$ for plant material) in tin capsules on a micro-analytical balance and analyzed on a Carlo Erba NC 2100 elemental analyzer interfaced to a Thermo Electron Delta Plus XL isotope-ratio mass spectrometer. Carbon- and nitrogen-stable-isotope ratios were analyzed simultaneously from the same sample. Replicate analyses of an internationally recognized standard (National Institute of Standards \& Technology 1547 , peach leaves) were precise to $\pm 0.2 \%$ or both $\delta^{13} \mathrm{C}$ and $\delta^{15} \mathrm{~N}$. $\delta^{13} \mathrm{C}$ values were normalized on the VPDB scale using 2 standards available from the International Atomic Energy Association (IAEA): IAEA-CH6 $\left({ }^{13} \mathrm{C}=-10.4 \%\right.$ ) and IAEA-CH7 $\left(\delta^{13} \mathrm{C}=-31.8 \% o\right) . \delta^{15} \mathrm{~N}$ values were normalized on the AIR scale using IAEA-N $1\left(\delta^{15} \mathrm{~N}=\right.$ $0.4 \% o)$ and IAEA-N2 $\left(\delta^{15} \mathrm{~N}=20.3 \% o\right)$.

Isotope ratios were expressed in \%o as

$$
\delta^{\mathrm{N}_{\mathrm{E}}}=1000\left(\mathrm{R}_{\text {sample }} / \mathrm{R}_{\text {standard }}-1\right)
$$

where $\mathrm{N}$ is the mass of the heavy isotope of element $\mathrm{E}$, and $\mathrm{R}$ is the ratio of the heavy isotope to the light isotope $\left({ }^{13} \mathrm{C} /{ }^{12} \mathrm{C}\right.$ and $\left.{ }^{15} \mathrm{~N} /{ }^{14} \mathrm{~N}\right)$. The $\delta$ values were reported relative to the international standards of ViennaPeeDee Belemnite marine limestone (VPDB) and atmospheric N2 (AIR), for $\delta^{13} \mathrm{C}$ and $\delta^{15} \mathrm{~N}$, respectively. We used a linear mixing model (ISOERROR 1.04) to determine the proportion of $\mathrm{C}_{3}$ and $\mathrm{C}_{4}$ plants in the diet of Mogollon voles (Phillips and Gregg 2001).

\section{Statistical Analysis}

We used multiresponse permutation procedures (MRPP for single-factor designs; Zimmerman et al. 1985) to detect differences in diet as indicated by $\delta^{13} \mathrm{C}$ and $\delta^{15} \mathrm{~N}$ between sexes, age classes, and locations by year. If sex or age class was not identified for a sample, it was excluded from analyses. We also compared diet by season (winter, spring, summer, fall) for specimens from the NAU mammals collection. These tests detect concentration within a priori groups. For these analyses we 


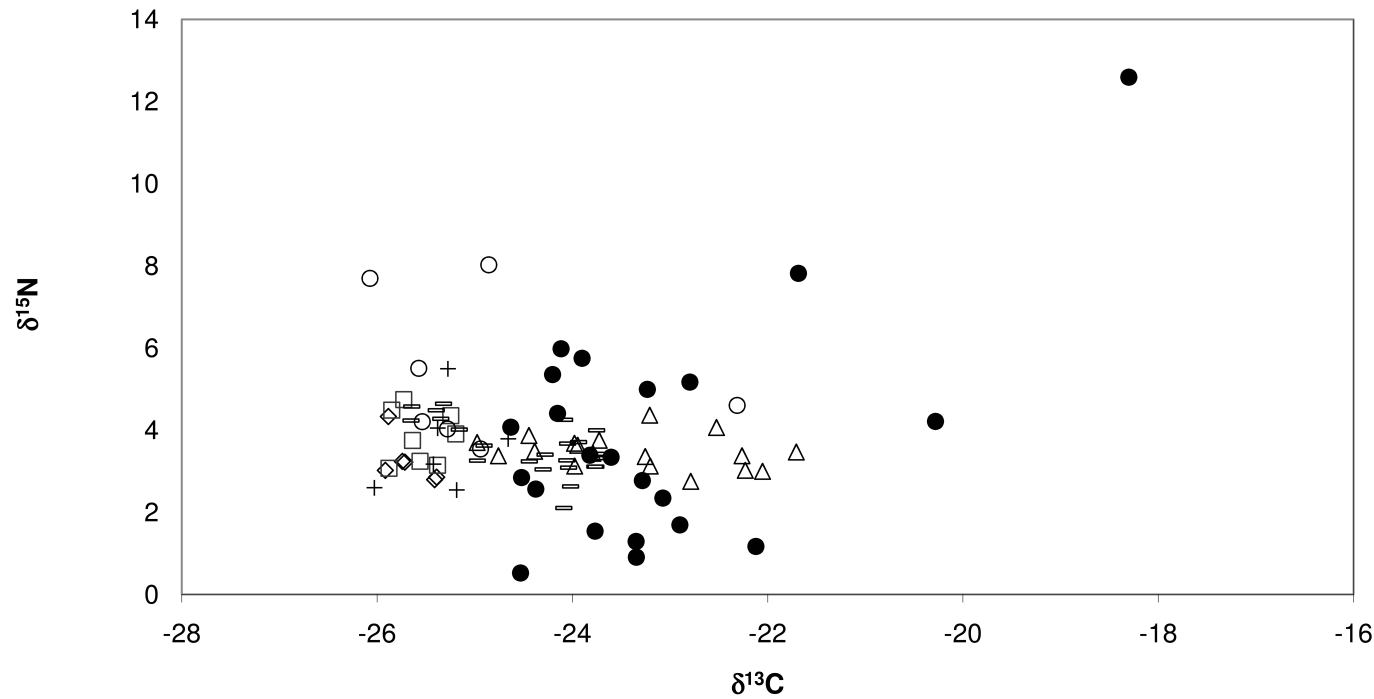

Fig. 1. Values of $\delta^{15} \mathrm{~N}$ vs. $\delta^{13} \mathrm{C}$ from hair samples taken from Mogollon voles that were live-trapped in northern Arizona or were from the Mammals Collection at Northern Arizona University collected between 1967 and 1979. Figure symbols: June 2001 riparian meadows (open squares), October 2001 riparian meadows (open diamonds), June 2002 riparian meadow (dashes), summer 2002 dry meadow (open triangles), June 2003 riparian meadow (plus signs), June 2003 dry meadow (open circles), mammals collection (filled circles).

TABLE 2. $\delta^{13} \mathrm{C}$ and $\delta^{15} \mathrm{~N}$ values from plants sampled in riparian and dry meadows where Mogollon voles (Microtus mogollonensis) were captured in northern Arizona, 2001-2003.

\begin{tabular}{|c|c|c|c|}
\hline Plant species & Common name & $\delta^{13} \mathrm{C}$ & $\delta^{15} \mathrm{~N}$ \\
\hline \multicolumn{4}{|l|}{ RIPARIAN MEADOWS } \\
\hline \multicolumn{4}{|l|}{$\mathrm{C}_{3}$ plants } \\
\hline Elymus trachycaulis & slender wheatgrass & -28.2 & -1.5 \\
\hline Pascopyrum smithii & western wheatgrass & -28.1 & -0.5 \\
\hline Carex praegracilis & clustered field sedge & -27.4 & -0.1 \\
\hline Eleocharis palustris & common spikerush & -27.4 & 0.2 \\
\hline Juncus arcticus var. mexicanus & Mexican rush & -26.7 & 1.9 \\
\hline Festuca ovina & sheep fescue & -25.9 & -0.6 \\
\hline Poa pratensis & Kentucky bluegrass & -25.4 & -1.1 \\
\hline \multicolumn{4}{|l|}{$\mathrm{C}_{4}$ plants } \\
\hline Bouteloua gracilis & blue grama & -15.3 & 0.9 \\
\hline Muhlenbergia wrightii & spike muhly & -14.1 & -0.0 \\
\hline Muhlenbergia rigens & deer muhly & -13.4 & -1.1 \\
\hline \multicolumn{4}{|l|}{ Dry Meadows } \\
\hline \multicolumn{4}{|l|}{$\mathrm{C}_{3}$ plants } \\
\hline Festuca arizonica & Arizona fescue & -26.2 & -1.8 \\
\hline Verbascum thapsus & woolly mullein & -26.1 & 1.6 \\
\hline Carex sp. & sedge & -25.9 & -0.1 \\
\hline \multicolumn{4}{|l|}{$\mathrm{C}_{4}$ plants } \\
\hline Muhlenbergia rigens & deer muhly & -15.2 & -0.4 \\
\hline Boutelou gracilis & blue grama & -14.9 & -1.3 \\
\hline Blepharoneuron tricholepis & pine drop seed & -14.6 & 0.2 \\
\hline Muhlenbergia montana & mountain muhly & -14.5 & -5.9 \\
\hline
\end{tabular}

assumed that a representative sample of the population was taken and that there was an equal probability of occurrence among groups. We used pairwise multiple comparisons among groups (Peritz closure method; Petrondas and Gabriel 1983) to test the null hypothesis that for each subset of groups, observations were similar among groups within the subset. We 
used Spearman rank correlations (Zar 1999) to determine whether a relationship existed between $\delta^{13} \mathrm{C}$ signatures for Mogollon voles we captured (2001-2003) and cumulative precipitation values (precipitation from the 12-month period preceding capture; Table 1). We set $\alpha$ $=0.05$ for all analyses.

\section{RESUlTS}

We detected no difference $(P \geq 0.5)$ between diets of male $\left(n=47, \delta^{13} \mathrm{C}=-24.2 \pm 0.2\right.$, $\left.\delta^{15} \mathrm{~N}=3.6 \pm 0.2\right)$ and female $\left(n=34, \delta^{13} \mathrm{C}=\right.$ $\left.-24.0 \pm 0.2, \delta^{15} \mathrm{~N}=4.0 \pm 0.3\right)$ voles as indicated by $\delta^{13} \mathrm{C}$ or $\delta^{15} \mathrm{~N}$. Nor did we detect differences for $\delta^{13} \mathrm{C}$ among voles of different age classes $\left(P=0.09\right.$; juvenile: $\delta^{13} \mathrm{C}=-24.0 \pm$ $0.4, n=5$; subadult: $\delta^{13} \mathrm{C}=-23.7 \pm 0.3, n=$ 12; adult: $\delta^{13} \mathrm{C}=-24.5 \pm 0.2, n=31$ ). However, $\delta^{15} \mathrm{~N}$ differed among age classes $(P=$ 0.02 ). Adult and juvenile voles were similar in $\operatorname{diet}\left(P=0.3\right.$; adult: $\delta^{15} \mathrm{~N}=4.1 \pm 0.2$; juvenile: $\left.\delta^{15} \mathrm{~N}=3.7 \pm 0.2\right)$ but differed from subadults $\left(\delta^{15} \mathrm{~N}=3.2 \pm 0.1\right.$; juvenile: subadult $P=0.05$; adult: subadult $P=0.01$ ). Diet of subadults may reflect their adjustment to procuring food after weaning and during dispersal.

We did not detect differences in $\delta^{13} \mathrm{C}$ or $\delta^{15} \mathrm{~N}$ among season of capture for specimens collected between 1967 and $1979(P=0.06)$ (winter: $n=2, \delta^{13} \mathrm{C}=-24.0 \pm 0.1, \delta^{15} \mathrm{~N}=$ $4.7 \pm 1.3$; spring: $n=4, \delta^{13} \mathrm{C}=-21.7 \pm 1.5$, $\delta^{15} \mathrm{~N}=6.1 \pm 2.2$; summer: $n=11, \delta^{13} \mathrm{C}=$ $-23.3 \pm 0.2, \delta^{15} \mathrm{~N}=2.4 \pm 0.5$; fall: $n=6, \delta^{13} \mathrm{C}$ $=-23.9 \pm 0.5, \delta^{15} \mathrm{~N}=4.9 \pm 1.0$; Fig. 1). However, we noted a trend for more enriched $\delta^{13} \mathrm{C}$ in spring diet compared with summer diet of voles $(P=0.09)$, suggesting that diet between late winter and spring could differ from summer diet. Small samples sizes likely limited our ability to detect significant differences.

We found few differences for voles among locations and years for $\delta^{15} \mathrm{~N}$, but $\delta^{13} \mathrm{C}$ varied among both (Table 1, Fig. 1). During years with higher precipitation, $\delta^{13} \mathrm{C}$ was more depleted $(n=6, R=-0.81, P=0.05$; Table $1)$. The $\delta^{13} \mathrm{C}$ values that we sampled in meadows ranged from -28.2 to -25.4 for $\mathrm{C}_{3}$ plants and from -15.3 to -13.4 for $\mathrm{C}_{4}$ plants (Table 2). The $\delta^{15} \mathrm{~N}$ values for vegetation varied between -5.86 and 1.85. Stable-isotope signatures indicated that voles were primarily herbivorous (mean \pm standard error for $\delta^{15} \mathrm{~N}=3.8 \pm 0.2$ $\%$ ) and, according to the mixing model, used
$\mathrm{C}_{3}$ plants $(70 \% \pm 3 \%)$, although a smaller percentage $(30 \% \pm 3 \%)$ of their diet included $\mathrm{C}_{4}$ plants.

Dominant $\mathrm{C}_{3}$ plants in meadows were clustered field sedge, western wheatgrass, Arizona fescue, and Kentucky bluegrass; $\mathrm{C}_{4}$ dominants were deer and spike muhly. We found signs of herbivory by Mogollon voles, indicating they fed on clustered field sedge. They built runways under common spikerush (Eleocharis palustris), sheep fescue (Festuca ovina), Arizona fescue, and deer muhly.

\section{DisCUSSION}

Many herbivores select $\mathrm{C}_{3}$ over $\mathrm{C}_{4}$ plants as food sources because $\mathrm{C}_{3}$ plants have higher nutritional content and digestibility (Gannes et al. 1998). Our data indicated that Mogollon voles fed primarily on $\mathrm{C}_{3}$ plants, despite the availability and dominance of $\mathrm{C}_{4}$ plants. Frey et al. (2002) found that ground cover of forbs and grasses during capture periods for Mogollon voles included Idaho fescue (Festuca idahoensis), western wheatgrass, and timothy (Phleum pratense), all $\mathrm{C}_{3}$ plant species (Williams 1974, Brown 2004). Yarborough (2006) surveyed 13 meadows in northern Arizona in 2002 and failed to detect sign (runways) of Mogollon voles in 6 of these. These meadows lacked the dense understory vegetation typical of meadows that had runways and in some cases were dominated by $\mathrm{C}_{4}$ plants such as blue grama. Blue grama did not appear to provide structure for adequate cover for Mogollon voles and also may be inadequate as a food source. Dominant plants (Arizona fescue, deer muhly, spike muhly, western wheatgrass, Kentucky bluegrass, clustered field sedge) where we captured more voles formed dense, tall (e.g., $\geq 35$ $\mathrm{cm})$ clumps in dry meadows or continuous cover in riparian meadows (C.L. Chambers unpublished data). Plants often leaned or collapsed so that grasses formed mats over runways, and runways thus functioned as tunnels. Both $\mathrm{C}_{3}$ and $\mathrm{C}_{4}$ plants were used as cover for runways, so $\mathrm{C}_{4}$ plants may in part have been ingested by Mogollon voles as they constructed new runways or cleared old runways.

Average fractionation of carbon isotopes between diet and hair in mammalian herbivores was $+2 \%$ to $+3 \%$ (Sponheimer et al. 2003, Dearing unpublished data), suggesting that the amount of $\mathrm{C}_{3}$ in the diet of Mogollon voles 
might be underrepresented by carbon-stableisotope analysis. Based on Sponheimer et al. (2003), the amount of $\mathrm{C}_{3}$ plant species in the diet of Mogollon voles actually might be $>70 \%$. $\mathrm{C}_{3}$ plants appeared to be the dominant food source, although $\mathrm{C}_{4}$ plants did contribute in lower quantities to the diet of Mogollon voles.

Although we did not compare availability of $\mathrm{C}_{3}$ and $\mathrm{C}_{4}$ plants to their use by Mogollon voles, we did not find runways in areas without dense grasses, and these areas were usually dominated by a mix of $\mathrm{C}_{3}$ and $\mathrm{C}_{4}$ plants. Despite availability of both, voles appeared to feed primarily on $\mathrm{C}_{3}$ plants. Additional work can clarify whether Mogollon voles can use dense grasslands where $\mathrm{C}_{4}$ plants are dominant or whether this species is limited to areas dominated by $\mathrm{C}_{3}$ plants because of diet selection. At least 1 vole species, the montane vole (Microtus montanus), can live in habitat dominated by $\mathrm{C}_{4}$ plants. Montane voles fed almost exclusively on $\mathrm{C}_{4}$ salt grasses year-round in salt marshes bordering the Great Salt Lake, Utah (Dearing personal communication).

We suspect that the diet of Mogollon voles might vary seasonally. Mogollon voles captured in spring had $\delta^{13} \mathrm{C}$ that appeared more enriched $\left({ }^{13} \mathrm{C}=-21.7\right)$ than captures during other seasons $\left(\delta^{13} \mathrm{C} \leq-23.3\right)$. Although not statistically significant, this trend suggests a difference in food selection or availability following winter. During seasons when foods are limiting, voles might be less selective or forced to use other foods (e.g., Cherry and Verner 1975) such as $\mathrm{C}_{4}$ plants, resulting in more enriched ${ }^{13} \mathrm{C}$ values in hair samples. Batzli and Pitelka (1971) found changes in diet of the California vole (Microtus californicus) between seasons. High vole populations reduced preferred foods and forced animals to select others. For Mogollon voles, high densities or limited foods during late winter and spring could change diet.

We also may have found evidence that Mogollon voles feed on insects, thus affecting both $\delta^{13} \mathrm{C}$ and $\delta^{15} \mathrm{~N}$ signatures. Prairie voles (Microtus ochrogaster) supplement their diet with seeds and insects in poorer quality habitat (Cole and Batzli 1979). Brower et al. (1985) found that Mexican voles feed on overwintering monarch butterflies (Danaus plexippus) in Mexico. If plant foods become limiting, insects might become an alternative source for Mogollon voles. From our data, this did not appear to be a common occurrence. Most voles we sampled had $\delta^{15} \mathrm{~N}<8 \%$, with the average (3.8\%o) indicating Mogollon voles were primary consumers feeding directly on plants (Fig. 1). However, we did sample a single individual with high $\delta^{15} \mathrm{~N}(12.6 \%$ ), which might indicate this animal was a secondary consumer (fed on insects; e.g., Gannes et al. 1998). Alternately, it might indicate that the animal was starving (Gannes et al. 1997). This pregnant female was captured during late spring (1 May 1972, NAU 2210), at a time when food might have been limiting.

In Mogollon vole hair, $\delta^{13} \mathrm{C}$ was negatively correlated with precipitation from the 12-month period preceding capture, indicating that vole hair was capable of recording environmental conditions. Plant $\delta^{13} \mathrm{C}$ can reflect past changes in climate (e.g., Ehleringer and Cerling 1995). Mammalian hair might therefore be a useful indicator of past environmental conditions since, in our case, hair reflected annual moisture regimes. However, the correlation we found could be coincidental or due to subtle changes in the relative proportion of $\mathrm{C}_{3}$ and $\mathrm{C}_{4}$ plants in Mogollon vole diet.

Grazing could alter availability of both food and cover for Mogollon voles. Livestock and wild ungulates (e.g., elk, Cervus elaphus) use meadows where we captured voles. In some areas, grazing had reduced plant biomass by one-half to three-quarters (e.g., from an average of $3000 \mathrm{~kg} \cdot \mathrm{ha}^{-1}$ in ungrazed areas to 1150 $\mathrm{kg} \cdot \mathrm{ha}^{-1}$ in grazed areas) and reduced cover from an average of 31 to $12 \mathrm{~cm}$ height (C.L. Chambers unpublished data). Grazing can also affect plant composition (Chambers and Holthausen 2000). Since grazers often select $\mathrm{C}_{3}$ over $\mathrm{C}_{4}$ plants (Gannes et al. 1998), overgrazing could reduce cover and eliminate plants that are of higher nutritive value to Mogollon voles. The Mogollon vole's selection of $\mathrm{C}_{3}$ plants as food sources makes it a useful indicator species for land-management agencies in the Southwest. Monitoring Mogollon voles through live-trapping or the use of a rapid assessment technique (runway density and fecal pellet sampling; Yarborough and Chambers 2007) could be used to indicate grazing levels that are sustainable for this species.

\section{ACKNOWLEDGMENTS}

We appreciate the support of the Coconino and Kaibab National Forests for help with 
funding and selecting sites. We thank $\mathrm{T}$. Theimer for assistance with the NAU Mammals Collection. We also thank V. Alm, D. Bernardos, R. Burns, J. Corbett, A. Gatto, S. Kyle, D. Mummert, M. Painter, H. Reading, and F. Yarborough for assisting with live-trapping. J. Springer, M. Nazaire, and B. Reif helped with plant sampling and identification. We thank D. Dearing, J. Ganey, and T. Sisk for reviewing this manuscript.

\section{Literature Cited}

Adams, H.D., AND T.E. KoLb. 2004. Drought response of conifers in ecotone forests of northern Arizona: tree ring growth and leaf $\delta^{13} \mathrm{C}$. Oecologia 140:217-225.

aL-Khateeb, A., AND E. Johnson. 1971. Seasonal changes of pelage in the vole (Microtus agrestis). II. The effect of day length. General and Comparative Endocrinology 16:229-235.

ARmstrong, D.M. 1972. Distribution of mammals in Colorado. University of Kansas, Museum of Natural History Monograph 3:1-415.

Batzli, G.O., and F.A. PitelKa. 1971. Condition and diet of cycling populations of the California vole, Microtus californicus. Journal of Mammalogy 52:141-163.

BoutTon, T.W. 1991. Stable carbon isotope ratios of natural materials II: Atmospheric, terrestrial, marine and freshwater environments. Pages 173-186 in D.C. Coleman and B. Fry, editors, Carbon isotope techniques. Academic Press, San Diego, CA.

Brower, L.P., B.E. Horner, M.A. Marty, C.M. MoffitT, B. Villa-R. 1985. Mice (Peromyscus maniculatus, P. spicilegus, and Microtus mexicanus) as predators of overwintering Monarch butterflies (Danaus plexippus) in Mexico. Biotropica 17:89-99.

BRown, C.S. 2004. Are functional guilds more realistic management units than individual species for restoration? Weed Technology 18:1566-1571.

Chambers, C.L., and R.S. Holthausen. 2000. Montane ecosystems used as rangelands. Pages 213-280 in R. Jemison and C. Raish, coeditors, Livestock management in the American Southwest: ecology, society, and economics. Elsevier Science, Amsterdam, The Netherlands.

Cherry, R.H., and L. Verner. 1975. Seasonal acclimatization to temperature in the prairie vole, Microtus ochrogaster. American Midland Naturalist 94:54-360.

Cole, F.R., AND G.O. BATZLI. 1979. Nutrition and population dynamics of the prairie vole, Microtus ochrogaster, in central Illinois. Journal of Animal Ecology 48:455-470.

Conley, W. 1976. Competition between Microtus: a behavioral hypothesis. Ecology 57:224-237.

DeNiro, M.J., AND S. EPSTEIN. 1978. Influence of diet on the distribution of carbon isotopes in animals. Geochimica et Cosmochimica Acta 42:495-506.

. 1981. Influence of diet on the distribution of nitrogen isotopes in animals. Geochimica et Cosmochimica Acta 45:341-351.

Ehleringer, J.R. 1991. ${ }^{13} \mathrm{C} /{ }^{12} \mathrm{C}$ fractionation and its utility in terrestrial plant studies. Pages 187-201 in D.C. Coleman and B. Fry, editors, Carbon isotope techniques. Academic Press, San Diego, CA.
Ehleringer, J.R., and T.E. Cerling. 1995. Atmospheric $\mathrm{CO}_{2}$ and the ratio of intercellular to ambient $\mathrm{CO}_{2}$ concentrations in plants. Tree Physiology 15:105-111.

Elheringer, J.R., A.E. HaLl, and G.D. Farouhar. 1993. Stable isotopes and plant carbon-water relations. Academic Press, New York.

Frey, J.K. 1995. Mammals of the Negrito Creek Watershed, Gila National Forest, Reserve Ranger District, Catron County, New Mexico. A final report submitted to Gila National Forest, Reserve District, United States Forest Service.

Frey, J.K., AND C.T. LaRue. 1993. Notes on the distribution of the Mogollon vole (Microtus mogollonensis) in New Mexico and Arizona. Southwestern Naturalist $38: 176-178$.

Frey, J.K., J.J. Root, C.A. Jones, C.H. Calisher, and B.J. BEATY. 2002. New records of the Mogollon vole, Microtus mogollonensis (Mearns 1890), in southwestern Colorado. Western Northern American Naturalist 62:120-123.

Frey, J.K., AND T.L. YATES. 1995. Hualapai vole (Microtus mogollonensis hualpaiensis) genetic analysis. Unpublished report to the Arizona Game and Fish Department, Phoenix, AZ.

GanNES, L.Z., C.M. DEL Rio, AND P. Koch. 1998. Natural abundance variations in stable isotopes and their potential uses in animal physiological ecology. Comparative Biochemistry and Physiology 119A:725-737.

Gannes, L.Z., D.M. O’Brien, C. Martinez del Rio. 1997. Stable isotopes in animal ecology: assumptions, caveats, and a call for more laboratory experiments. Ecology 78:1271-1276.

Hilton, B.L. 1976. The reproductive biology of the Mexican vole, Microtus mexicanus. Master's thesis, Northern Arizona University, Flagstaff.

KELLY, J.F. 2000. Stable isotopes of carbon and nitrogen in the study of avian and mammalian trophic ecology. Canadian Journal of Zoology 78:1-27.

Kime, K.A., W.E. Van Pelt, and D.W. Belitsky. 1995. The Hualapai Mexican vole in northwestern Arizona: 1990-1995 field investigations. Technical Report 75, Arizona Game and Fish Department, Phoenix.

Kuhlmann, M.T., G. Clemen, and S. Schlatt. 2003. Molting in the Djungarian hamster (Phodopus sungorus Pallas): seasonal or continuous process? Journal of Experimental Zoology 295A:160-171.

LIDICKER, W.Z., JR. 1973. Regulation of numbers in an island population of the California vole, a problem in community dynamics. Ecological Monographs 43: 271-302.

Macko, S.A., M.H. Engel, V. Andrusevich, G. Lubec, T.C. O'ConnelL, And R.E.M. Hedges. 1999. Documenting the diet in ancient human populations through stable isotope analysis of hair. Philosophical Transactions of the Royal Society of London B Biological Sciences 354:65-76.

Martin, E.P. 1956. A population study of the prairie vole (Microtus ochrogaster) in northeastern Kansas. University of Kansas Publication of the Museum of Natural History 8:361-416.

Petrondas, D.A., and K.R. Gabriel. 1983. Multiple comparisons by rerandomization tests. Journal of the American Statistical Association 78:949-957.

Phillips, D.L., AND J.W. GregG. 2001. Uncertainty in source partitioning using stable isotopes. Oecologia 127:171-179. 
Spicer, R.B., R.L. Glinski, And J.C. DEVos, JR. 1985. Status of the Hualapai vole (Microtus mexicanus hualpaiensis Goldman). Unpublished report to U.S. Fish and Wildlife Service. Arizona Game and Fish Department, Phoenix.

Sponheimer, M., T. Robinson, L. Ayliffe, B. Passey, B. Roeder, L. Shipley, E. Lopez, et AL. 2003. An experimental study of carbon-isotope fractionation between diet, hair, and feces of mammalian herbivores. Canadian Journal of Zoology 81:871-876.

STEED, J.E. 2001. Evaluation of Carex species for use in restoration of southwestern riparian meadows. Master's thesis, Northern Arizona University, Flagstaff.

Tamarin, R.H. 1985. Biology of the New World Microtus. American Society of Mammalogists Special Publication Number 8. 893 pp.

West, A.G., L.K. Ayliffe, T.E. Cerling, T.F. Robinson, B. Karren, M.D. Dearing, and J.R. Ehleringer. 2004. Short-term diet changes revealed using stable carbon isotopes in horse tail-hair. Functional Ecology 18:616-624.

Western Regional Climate Center. 2006. Historical climate information. Flagstaff WSO AP, Arizona. Period of Record Monthly Climate Summary [accessed 2 April 2006]. Available from: http://www.wrcc .dri.edu/cgi-bin/cliMAIN.pl?azflag
Williams, G.J., III. 1974. Photosynthetic adaptation to temperature in $\mathrm{C}_{3}$ and $\mathrm{C}_{4}$ grasses: a possible ecological role in the shortgrass prairie. Plant Physiology 54:709-711.

Winstead, R.A., J.R. Koehler, and J.L. Cordova. 1999. Hualapai Mexican vole investigations on the Prescott National Forest. Technical Report 158, Arizona Game and Fish Department, Phoenix.

Yarborough, R.F. 2006. Using Mogollon vole (Microtus mogollonensis) sign to predict Mogollon vole presence in northern Arizona. Master's thesis, Northern Arizona University, Flagstaff.

Yarborough, R.F., AND C.L. Chambers. 2007. Using visual evidence of Mogollon voles (Microtus mogollonensis) to predict their presence in northern Arizona. Southwestern Naturalist 52:511-519.

ZAR, J.H. 1999. Biostatistical analysis. 4th edition. Prentice May, Upper Saddle River, NJ. 663 pp.

Zimmerman, G.M., H. Goetz, and P.W. Mielke, JR. 1985. Use of an improved statistical method for group comparisons to study effects of prairie fire. Ecology 66:606-611.

Received 16 February 2007 Accepted 31 October 2007

APPENDIX. Specimens examined for stable-isotope signatures: 23 specimens of Microtus mogollonensis (formerly Microtus mexicanus) in the Mammals Collection at Northern Arizona University.

San Francisco Peaks, Schultz Pass $(n=3)$ : collected 6 October 1967, 1 male (NAU 262, $\delta^{13} \mathrm{C}$ only), 2 females (1 pregnant, 1 recent parturition) (NAU 264, 265).

Hart Prairie $(n=1)$ : collected 16 December 1968 in ponderosa pine forest, Festuca and blue grama understory, Coconino National Forest, sex unknown (NAU 730).

North of Walnut Canyon $(n=1)$ : collected 24 March 1968 in pinyon-juniper woodland, 4.8 km north of Walnut Canyon, sex unknown (NAU 731).

Inner Basin, San Francisco Peaks, Coconino County $(n=6)$ : collected 29 June to 11 August 1969, 3 males, 3 females (1 pregnant, 1 lactating, 1 unknown condition) (NAU 1775, 1782, 1786, 1793, 1796, 1797).

Unknown location $(n=1)$ : male collected 1 June 1971 (NAU 2211).

Inner Basin, San Francisco Peaks, Fremont Saddle, Coconino County $(n=1)$ : male collected 20 August 1971 (NAU 2355).

Beaver Creek Watershed Unit 12, $64 \mathrm{~km}$ southeast of Flagstaff $(n=3)$ : collected 11 November 1971 and 7-8 Apr 1972, 2 females (pregnant), 1 male (NAU 2553, 2554, 2555).

Ashurst Lake, west shore, Coconino County $(n=1)$ : pregnant female collected 1 May 1972 (NAU 2210).

Hart Prairie, Coconino National Forest $(n=3)$ : 1 male, 2 pregnant females collected 23 June 1972 and 9 July 1972 (NAU 2425, 2426, 2427).

Coconino County, Route 180, $4 \mathrm{~km}$ west of Flagstaff $(n=1)$ : nonreproductive female captured 12 September 1976 (NAU 3611).

Coconino County, N. Paradise Road, Flagstaff $(n=1)$ : male captured 30 November 1976 (NAU 4169).

Coconino County, Lindberg Springs, $8 \mathrm{~km}$ south of Flagstaff $(n=1)$ : male captured 17 February 1979 (NAU 3704 ). 